\title{
Changing Ways of Calling for Change: Media Coverage of the 1992 Campaign*
}

\author{
Robert L. Savage, University of Arkansas, Fayetteville
}

The 1992 Presidential campaign proved to be the ultimate media campaign of the past two decades during which this electioneering mode has dominated American politics. The essay that follows is framed primarily in terms of major foci shaping the mediated aspects of such campaigns, including the framing of the initial campaign and the eventual winnowing of the candidates, press performance and media bias, campaign advertising, and televised debates. In addition, two major elements shaping media coverage that were more or less unique to the 1992 campaign are examined. While tentative efforts were taken by journalists in 1988 and 1990 to mediate candidate-produced messages, the 1992 campaign is the first in which a number of media organizations attempted some systematic efforts in this regard. Moreover, the Ross Perot candidacy was the most important "third-party" candidacy in eight decades, producing a number of changes in the process of media coverage for a Presidential campaign. In sum, from a communication perspective, it was a very interesting campaign, the portents of which are unclear at present.

From the standpoint of media coverage, the 1992 Presidential campaign was probably the most exciting campaign in American history, albeit probably not the most dramatic. Indeed, I would argue that the electoral decision process itself, once it was clear that Bill Clinton had locked up the Democratic Party nomination, marched inexorably to its eventual conclusion. The combination of unusually pervasive media coverage and the lock-step march to an electoral decision account for the widespread perception that it was a never-ending campaign as well as to produce the collective sigh of national relief on November 4, 1992, signalling that it was finally over.

Assuredly, the campaign and its outcome could have been different both before and after the Democratic Party convention if key actors or organizations had made strikingly different decisions or if major systemic changes, such as significant economic improvement, had occurred. However, especially after the Republican convention, media coverage primarily served to maintain major perceptual patterns of the electoral situation among prospective voters. The one major exception was the re-entry of Ross Perot into the race as an independent candidate. Even this exception served to reinforce the perception of an interminable campaign because it added all the more to the media coverage of the campaign. ${ }^{1}$

Robert L. SAVAge is Professor and Chair of Political Science at the University of Arkansas, Fayetteville, and has served as President of the Southwestern Political Science Association.

The American Review of Politics, Vol. 14, Summer, 1993: 213-228

C 1993 The American Review of Politics 
Media coverage of the 1992 presidential election campaign was much more pervasive than in any previous presidential election year. This is apparent not only in the sense of greater coverage of the usual topics of preprimary maneuvering, the race to secure delegates and the nomination, what the national conventions reveal about the candidates and their party coalitions, and the impact of the candidate debates, but also in the sense of breaking new ground; specifically, the candidates' extension of their "earned media" strategies to include entertainment programming, the news organizations' first systematic attempts to police candidates' claims in speeches and in commercials, and the numerous attention-getting innovations generated by the independent campaign of $\mathrm{H}$. Ross Perot.

Perhaps partly because of this circus of coverage, many prospective voters found themselves wavering until the very end, despite the fact that the essential running positions of the candidates did not change during the postconvention period. Indeed, the consortium exit poll conducted nationally by Voter Research \& Surveys found that 42 percent of all voters made their decision during the last two weeks of the campaign, and more than a third of these late deciders (16 percent of all voters) reported that they made up their minds in the last three days before the election. To understand the vagaries of the American electoral mind at such a late hour of the 1992 election contest, we need to begin our analysis almost exactly one year earlier, during the initial framing of the campaign and the ensuing process of winnowing the candidates, before proceeding to discussion of the topics of press performance and media bias, the mediating of campaign mediation, the Perot factor, campaign advertising, and the role of the October debates.

\section{Framing the Campaign and the Winnowing Process}

During the period between the end of Operation Desert Storm and November 1991, media speculation about the forthcoming presidential campaign focused largely upon what dragons might issue forth from the Democratic lair to do battle with the Republican incumbent, George the Invincible. By the latter date, however, only one dragon, Governor Mario Cuomo of New York, continued to belch smoke from that lair. The six announced Democrats entering the lists widely were characterized as dwarfs. As the month passed, the seemingly strongest contender once again dematerialized, behind all the smoke, into Mario the Incalculable. Following his last belch, the smoke cleared and the six dwarfs were left to contend with one another for what most regarded as the unenviable opportunity to joust with St. George. ${ }^{2}$ 
The following month, however, it became clear that the President was not to get a free ride to the final tournament. Pat Buchanan and David Duke announced their intentions to unhorse their party's standard bearer.

While it seemed unlikely that George Bush ultimately would lose his party's nomination, media organizations were confronted with the prospect of covering nine campaigners in the early primaries and caucuses - a daunting prospect economically, especially for the major television networks, which had undergone serious personnel and budget cutbacks in recent years. Technology, however, permitted some innovative efforts at economizing. Satellite feeds and camera pools, for example, reduced the need for onsite personnel representing both electronic and print media.

The Democratic and Republican challengers generally embraced and advantaged themselves of these innovations. There were, nonetheless, harbingers of trouble already for the candidates. A satellite feed caught one of the Democratic candidates, Senator Bob Kerrey of Nebraska, relating an insensitive joke to another candidate, Governor Bill Clinton of Arkansas. Perhaps media analysts had overrated the "dynamism" of Kerrey to begin with; however, whatever Kerrey's abilities, he subsequently was not able to regain his composure for the campaign.

The budgets of the national media organizations also gained some respite from the absence of the Iowa factor early in the presidential campaign. Given the incumbent's organizational strength in the Republican caucuses there, and Democratic Senator Tom Harkin's "favorite son" status, Iowa held no dramatic interest for the media. All eyes focused upon New Hampshire's primary contest.

As revealing as the New Hampshire campaign was to be, as the occasion of Buchanan's telling, yet ultimately bankrupt bashing of Bush, Duke's virtual non-appearance, Governor Douglas Wilder's withdrawal, Jerry Brown's monotonous droning of his 800 number for contributions, and the fading of both Kerrey and Harkin, the story that best illuminates the role of the mass media there was leaked from without the state. The tabloid publication alleging Bill Clinton's affair with Gennifer Flowers assuredly had an immediate impact upon the primary as Clinton slipped from front-runner to finish second behind Paul Tsongas. More importantly, however, the event sparked a frenzy of coverage by "responsible" media outlets that on the one hand decried "scandal-sheet" politics but on the other justified themselves by claiming the initial publication itself as a newsworthy event.

Press performance assuredly is an element of consideration in all presidential campaigns, but not usually so primary as it was to prove to be from this point on in the 1992 campaign. Moreover, the frenzied coverage 
sparked a signal television broadcast that heralded a new strategic approach to that medium-although no one recognized it at the time. Shopping about for a venue for response, Bill and Hillary Clinton obtained the largest potential audience imaginable for a single sitting, a special interview on CBS's Sixty Minutes immediately following the network's broadcast of the Super Bowl game. The Clintons' performance hardly was stellar but it was sufficient to check any further significant slide in the polls. More importantly, their appearance heralded the opening of alternative routes for getting the message out.

There is still another aspect of mass media coverage of the New Hampshire primary to be considered, however. Candidate strategies, at least for the Democrats, necessarily were geared to attaining a level of contributions that would support costly advertising in future primaries and caucuses. Thus, the returns in New Hampshire sealed the doom of Kerrey and Harkin while providing a strong bubble of optimism for the Tsongas campaign organization. For different reasons, Clinton and Brown were not quite so dependent.

In contrast, candidate strategies for media outreach during the Super Tuesday primaries were not surprising. Indeed, for the most part, the candidates pursued set strategies in these state-by-state battles using whatever resources were available. National media outlets reported these efforts over the next several weeks with the usual focus on the horse race (i.e., number of delegates earned), at least for the Democrats. For the Republicans, on the other hand, the horse-race aspect was irrelevant. Instead, media attention focused increasingly on the declining solidarity of the party and on the President's plummeting personal popularity in the nation at large. It is the performance, however, of the national media that is of greater interest here.

\section{Press Performance and Media Bias}

There were many ironies in the 1992 presidential campaign, but a prime candidate for the greatest of these was the negative bias of media coverage perceived by the Bush campaign organization and Republicans generally. Certainly, these were not new complaints. One only has to remember George Bush as he dramatically confronted Dan Rather on camera in January, 1988, and the subsequent news report that a source inside CBS had warned Bush's camp that Rather had been rehearsing or "gaming" the interview with the intent of confronting Bush.

Yet, after Desert Storm, media reports almost invariably depicted Bush as invincible in the upcoming election. Indeed, there was considerable speculation that "major" Democratic contenders such as Governor Mario 
Cuomo, Senator Edward Kennedy, Senator Bill Bradley, and Senator Sam Nunn were deterred from entering the race because of this touted invincibility. The media glow of 1991 slipped into the media glum of 1992 for George Bush, however, and "bias" was the spin that the Bush campaign team promoted to explain this seeming reversal.

But this ironic twist actually came about because the media were persistent in reporting "realities" that did not redound to the credit or advantage of Bush or his administration: the realities of economic stagnation, Saddam Hussein remaining in power, the passing of the Cold War, and so on. And, too, the "vision thing" reappeared as a problem. Essentially, however, the President was beset by major changes in the nation and the world at large that reduced his capabilities for setting the public agenda. Given that it was an election year, there also were more challengers than usual attempting to shape that agenda, including conservative Republicans, the loudest of the President's critics. Fundamentally, however, the public's agenda and that promoted by the media merged into what became the hallmark indictment filed by the Clinton campaign organization - "It's the economy, stupid." And, as David Gergen (1992) pointed out, "for more than two decades Republicans have complained about press coverage, and yet their presidential candidates have won five out of six elections."

Republican candidates also may be more prone to perceive, or at least allege, media bias because one of their primary constituencies, those who label themselves as "conservatives," are likely to have the least confidence in media coverage. Pollster John Brennan has found this to be the case, at least with respect to newspapers (Public Perspective 1993, 22). Whether Republican candidates complain about media bias because of their own conservatism or because they perceive that such complaints will fall on responsive ears is a "chicken-or-egg" argument. The fact is, simply, that Republican candidates are especially prone to complain about the liberal bias of the media. In 1992, these complaints were taken to the greatest (if not necessarily the most logical) extreme, when Vice President Dan Quayle pointed to the entertainment components of the mass media as having such a bias-indeed, a bias against "traditional family values."

In 1992, however, Republican candidates assuredly were not the only ones to complain about their treatment by the mass media. Punctuated by the above Kerrey incident, constant vigilance in the presence of massive media coverage was practiced by all of the candidates. It was this defensiveness that promoted (albeit not caused) the move toward utilization of unconventional media venues. Causation is not indicated by the chronology of these media events provided in a 10 July 1992 issue of Entertainment Weekly ("Everybody's Talkin"'). The chronology begins with the Clintons' January 
26th appearance on 60 Minutes, a defensive but hardly radical choice of outlet. The next appearance, however, comes from "out of left field," and involves a person not even a candidate as the television program started: on 20 February 1992, Ross Perot tossed his independent hat into the ring on Larry King Live, where he reappeared on 16 April. Prior to that return visit, however, Clinton countered the bashing he received from New York media prior to that state's primary election by appearing on Donahue on 1 April 1992 - a bold, innovative, and definitely defensive reaction to perceived media bias. Was it "a presidential performance by Clinton? Nosir. A uniquely American television moment? Heck, alas, yes" (Entertainment Weekly 10 July 1992, 16).

On 3 May 1992, Ross Perot took a step backward by appearing on Meet The Press, a more traditional venue, albeit one not used previously by presidential candidates. "By the end, he [came] off as ill-informed-and crabbier than Yosemite Sam" (Entertainment Weekly 10 July 1992). No doubt, the experience confirmed whatever distaste Perot already may have had for news reporters. He avoided any similar program in the future. On 29 May 1992, he appeared with his wife on 20/20, receiving the full Barbara Walters treatment. On 11 June, and again on 24 June, Perot responded to call-ins on Today. On the evening of the latter appearance, he returned for a third visit to Larry King Live, where it all had started. Then, on 29 June, Perot got his own show on ABC (albeit with Peter Jennings as moderator): A National Town Meeting: Who Is Ross Perot?

In the meantime, Bill Clinton also took to these new venues, generally with more success. On 3 June 1992, he appeared on The Arsenio Hall Show, playing his saxophone and generally seeming to have fun (Brummett 1992; Golson and Range 1992b). ${ }^{4}$ Clinton also was the first to do a live call-in morning show on network television, appearing on Today two days before Ross Perot did. Clinton bought time on NBC for 12 June, but the half-hour show proved to be his worst performance in these sundry attempts to circumvent the usual media formats. Three days later, he appeared on $C B S$ This Morning with still another new wrinkle, a live studio audience in addition to call-ins. The following day he made the definitive move into alternative venues by answering questions from a live audience of young people gathered for the MTV network special, Facing the Future with Bill Clinton.

There was other ground to be broken during the campaign, most notably by Ross Perot in targeting satellite feeds to local "conventions" of his followers and in the introduction of the "infomercial" after re-entering the campaign during the fall. George Bush followed Clinton and Perot into these new venues hesitantly and in a limited way (see Golson and Range 1992b, 19). 
Indeed, Bush's most celebrated involvement with such programming consisted of the White House announcement that the President would not appear on The Arsenio Hall Show on 10 June, which set the program's host up for a gleeful evening of jabs at the President's expense.

All these ventures beyond the traditional campaign venues might have been written off by the media as mere avoidance behavior on the part of the candidates. Ironically, however, news reports fastened upon these media events and actually extended their coverage. Even more ironic were the frequent confessions by media personnel that the events including audience participation produced more pertinent questioning than typically issued forth from themselves. Such confessions hardly speak well of journalistic performance during the 1992 campaign. On the other hand, the news media consequently examined much more actively not only their own reportage but also the messages transmitted more directly by the candidates and their minions.

It should be noted, however, that review of these media events by traditional news outlets was of no particular concern to candidate Clinton, and probably not the other candidates as well. In an interview shortly before Election day (Golson and Range 1992a, 15), Clinton was asked if he wanted the traditional news media to take seriously such events as appearances on Arsenio or MTV but to ignore tabloid reports. Clinton responded that he could not care less about such oversight, for "when people talk to me about Arsenio, they don't talk about what they read or heard about it; they talk to me abut what they saw on it."

\section{Mediating Mediation}

The media had begun to explore the problem of campaign advertising during the 1988 campaign, particularly as to its truthfulness. In 1992, both television networks and major newspapers featured "Ad Police," "Reality Checks," etc., in reviewing not only ads but speeches by the candidates and occasionally even those by their surrogates, as well. Such reviews focused not only upon truth narrowly defined but also upon the possibility of stringing truths together (or omitting them) so as to be misleading. Perhaps most surprising in this considerable extension of a recent innovation in news coverage was the lack of complaints forthcoming from the campaign organizations, especially given the frequent assertions of media bias.

CNN reporter Brooks Jackson (Election Debriefing 1992) believes that ads from the Bush-Quayle campaign were caught more often in these policing actions, probably because of their need to stretch farther given the context of conflicting economic indicators during the campaign season. Technological 
innovations and pooled camera coverage combined to permit the television networks, especially, to present rather compelling bits of debunking campaign rhetoric, whatever its source.

Such coverage is not without problems, nonetheless. Jackson (Election Debriefing 1992) points out, for example, that a number of media venues are largely out of reach for such review. He includes such new venues as satellite feeds to local radio and television stations and cassette tapes, both video and audio, distributed not only to local media outlets, but directly to prospective voters. A more fundamental problem, however, is pointed to by National Public Radio's Andy Bowers (Election Debriefing 1992). He argues that with the amount of campaign material readily accessible for media review, there still are far too many "facts," necessitating hard (subjective) decisions by media personnel as to which of these are going to be checked out.

Radio advertising presents a special problem in this regard. Audiotapes are extremely cheap to produce, thus allowing for a great degree of audience segmentation as to their regional distribution to radio stations. Such review is not impossible, inasmuch as one CBS Evening News "Reality Check" did take Clinton-Gore radio ads to task. Yet, systematic coverage is improbable. The improbability, however, is all the more disconcerting because, as Dean Rindy (1992) points out, "political campaigns are actually much nastier in direct mail and radio ads" than in television (and probably newspapers as well). He argues that they are nastier because there is more emotional distance between audiences and such media as mailings and radio ads.

While such reviewing of campaign rhetoric is not without its difficulties and even subject to some ethical problems (at least to the extent of unintended bias in the form of scrutinizing one campaign team over others), a more fundamental ethical dilemma of mediating mediation loomed larger than ever in 1992: the coverage of 'scandals.' Eric Engberg of CBS News (Election Debriefing 1992) distinguishes between what he calls the "straightforward campaign" and the "reptile campaign." The latter is characterized especially by partisan followers who press false and/or scandalous information about the opposition upon media representatives, information that very often is simply innuendo at best. Engberg relates his own experience in the New Hampshire primary, where upon his arrival in the state, a pro-Buchanan Republican notable asked him if he had checked the IRS returns of President Bush. Engberg ignored the innuendo.

At times, however, such reports are much less easy to ignore. Bill Clinton assuredly received much scandal coverage. All three major scandalsMs. Flowers, pot smoking, and draft dodging - may have begun to some extent very much like the case that Engberg relates, although there is 
strong reason to believe that a much more concerted effort underlies these revelations (see, e.g., Blumenthal 1992). In each case, however, responsible journalists ultimately had to acknowledge them in one way or another. The socalled draft-dodging incident was definitely newsworthy and of importance for voters' considerations. Moreover, candidate Clinton shared a substantial portion of the blame for dragging the issue out over such a long period of time. But none of these incidents or others such as the alleged mistress of George Bush brought about any enlightenment as to how the media ought to deal with these situations, or what defines purely personal matters of which the public has no cogent need to know. Moreover, these developments clouded another area of concern about media coverage during the campaign, that we loosely may call the "Perot factor."

\section{The Perot Factor}

The "reptile campaign" touched Ross Perot's independent candidacy for the Presidency just as it had the Clinton and Bush candidacies. Yet, his candidacy created major problems of still another order for media personnel. To begin with, some polls in the late spring showed him to be leading the two likely major party candidates, but he did not declare his own candidacy. He was as yet, and would remain until the fall, only a "private citizen," presumably not subject to the same scrutiny that can be applied to a declared candidate. At the same time, the "snakes" were coming forward with stories that often raised serious questions about Perot's fitness for public office. There are no rules for dealing with such a situation.

Moreover, Perot's own judgment about the appropriate role of the mass media in the electoral process raised even more questions. While we may never know why he held such a perception, it is clear that he believed that the mass media ought to be nothing more than impartial, uncritical conduits that routed messages directly to the citizenry. He would not concede an interpretive function for the press, even if he had not believed that all his expressions were so crystal clear that they required no further explication.

Ironically, Perot nevertheless was correct that most media reporters were hostile to him. The irony is that they were so receptive, even obliging, in providing him time or space in their outlets. NBC reporter Lisa Myers (Election Debriefing 1992) reports, for example, that Perot provided poor interviews particularly because he was extremely repetitious. Moreover, she and other media people resented his attacks on the media as just another part of the Republican "dirty tricks" campaign.

Ultimately, Perot became largely inaccessible to reporters. But CBS reporter Lesley Stahl (Election Debriefing 1992) points out that George Bush 
was no more accessible throughout the campaign, and that Bill Clinton became less and less accessible over time (see also Oman 1992). Nevertheless, she was able to help obtain an interview with Perot on 60 Minutes just nine days before the election. Perot began and ended as the media party's candidate.

\section{Political Advertising}

Most of the attention to this point has been placed upon free media space and time made available to the candidates. Yet, considerably more money was spent on advertising (especially via television) during the 1992 campaign than in any previous year. Herein lies another irony: advertising may have had less influence than anytime previously, at least in the era of modern media campaigning. That lack of effectiveness is demonstrated in a number of ways.

The Republicans have become the proverbial masters of mass media campaigns, a superiority that began to emerge in the Eisenhower campaigns of the 1950s and was sealed definitively by the Nixon campaign of 1968 . Democratic presidential candidates simply could not "get their acts together," definitively represented in the 1988 Dukakis campaign. Moreover, the Bush organization that same year mounted a campaign that was masterful, based upon the theme of the Vice President as "Heir Apparent" to the Reagan legacy. In 1992, the same advertising team came together again, albeit without two important original members, Roger Ailes and the late Lee Atwater.

However, before anyone rushes to the judgment that things would have been different if only Roger and Lee had been at the helm, consider that the theme of the previous campaign had become irrelevant for many reasons. The only notion that the 1992 team could - but ultimately did not - develop as a theme was to portray Bush as the "Man of Experience." Indeed, given the nature of the incumbent's "experience"- economic downturn, gridlock, world instability, etc. - the President himself at times seemed to want to present himself as an outsider. Harold Kaplan (Election Debriefing 1992), a member of the Bush campaign advertising team in both elections, reports that rather than a theme, the 1992 ads were guided by "a lot of little strategies," largely the result of week-to-week focus groups. Worse yet, the media "reality checks" often were so damaging that the advertising no longer could come together as an "agenda," but rather became a series of running targets.

At the same debriefing session, a chief Clinton media strategist, Mandy Grunwald boldly stated that their advertising did not affect the victory. 
Rather, the Clinton ads only served to increase the Electoral College margin through shrewd targeting. In a telling aside, however, she revealed that ads utilizing Bush speaking his own words proved especially effective. These video clips were inserted in ads to be shown in regional markets where the content had special — and negative - significance.

Grunwald's assertion of the limited impact of advertising is supported in part by some revealing exit poll data. Voter Research \& Surveys (1992) included a question asking voters what helped them to decide whom to vote for. The debates were chosen by 60 percent of the voters, 45 percent indicated talk shows, 25 percent pointed to the conventions, and only 23 percent felt that advertising was important. The most expensive venue for the candidatesand one that previous research had shown to be a more effective source of voter information than "earned media" on the nightly network news (Patterson and McClure 1976) - was considered the least important by the voters themselves. Assuredly, these survey responses must be taken with the proverbial grain of salt, since about a third of the voters (most of them no doubt strong partisans) had decided before the conventions. Still, many prospective voters were undecided as the debates finally unfolded.

The 1992 campaign potentially could have seen vicious negative advertising well in excess of that in any recent presidential campaign. In two articles during the summer, columnist Jack Anderson (1992a, 1992b) predicted just such a "dirty fight." He pointed particularly to a smear campaign targeted at Clinton regarding Gennifer Flowers, a campaign to be produced independently by Floyd Brown, author of the 1988 "Willie Horton" ad. That campaign fizzled, as did other such efforts (see, e.g., Norberg 1992; Solomon 1992). Perhaps media gatekeepers had become immunized during the primary season, and by all accounts most voters were not interested. Certainly, there were attack ads, often containing untruths, during the fall campaign; but outright sleaze fizzled.

\section{The Debates}

Debates in presidential campaigns now have a rich and lengthening history, although it appeared for a long time that the Kennedy-Nixon debates of 1960 might remain a unique episode in American electoral history. Since 1976, they seem to have become an essential, if not required, element of American presidential campaigns. Indeed, debates have diffused to electoral contests for many other offices in the United States in recent years. Despite such currency, however, the three 1992 presidential debates and the lone vicepresidential debate very nearly did not happen. 
Maureen Dowd (1992) offers an excellent analysis of why the debates have become so important for presidential campaigns in the modern media campaign. Essentially, she argues that the debate is a ritual "in which the candidates strive to show that they are superior in the knightly virtues of temperance, loyalty and courage." In a broader sense, Nimmo and Savage (1976, 63-69) pointed to such heroic aspects underlying candidate imagery as a perennial need that is not new to modern media campaigns. The trend away from the old-style, para-military, partisan campaign has left a ritualistic void that televised debates fill as the one clear way in which the candidates still face off with each other on Main Street at high noon. Despite, or because, of the clarification of choice such confrontations can produce, candidates continue to cautiously assess their needs for such image bolstering before taking that walk down the street toward their opponent.

Throughout the summer of 1992, the Bush campaign team resisted any commitment to any debate between the major candidates, presumably because the need for such a manly combat escaped them. While the polls did not support such optimism, the Bush people held out in the hope that the numbers eventually would reverse, placing them in a superior bargaining position concerning the number, dates, and formats of the debates, and ultimately even with respect to having any at all. In September, when reality finally prevailed, the Clinton team still held the superior bargaining position. And Clinton's primary representative in these discussions, Mickey Kantor, very nearly ended them when the Bush delegation persisted in refusing to have at least one debate in which questions came from the audience. Assuredly, history tells us that the Republicans acquiesced on that point: they needed the debates!

As we already have seen, there is at least post-hoc survey evidence suggesting that the 1992 presidential debates had considerable impact on the election contest, although not necessarily on the outcome. The size of the audiences drawn by the debates similarly suggests such impact. The first debate drew the largest audience for a debate since 1960. The second debate's audience, an estimated 88 million viewers, eclipsed even the 1960 record, only to be superceded by the third debate with more than 90 million viewers.

While there still were many undecided voters when the debates aired, that in itself would not explain the huge audiences. Very likely, a number of factors conjoined to bring so many to watch these political events unfold in October. Ed Fouhy, executive producer for the debates, reasons that putting them off to October, "when real people focus on politics," was an important factor (Election Debriefing 1992). He points also to the novelty of the three differing formats for the debate and the participation of "third- 
party" candidate Ross Perot. He further notes that the overlapping of the World Series did not have the predicted deleterious effect, since one of the teams participating was from a Canadian city. Moreover, many already decided voters no doubt watched to see if one of the candidates would "fall off the high wire."

Whatever the reasons, the debates were a crowning achievement for those who equate democracy with mass participation. Still, the end result in terms of electoral outcome remains unclear. For that matter, the future of debates in presidential elections is no clearer. That impacts and prospects are the subject of speculation does indicate, however, that there is some hope that review of the media coverage of the 1992 campaign might contain some insights regarding future campaigns.

\section{Some Concluding Observations With an Eye to the Future}

Countless discrete bits of information issue forth from an American presidential election, offering themselves up for analysis. But the analysis of this cross-sectional mosaic provides kaleidoscopic pictures shifting with every slight change in perspective. Focusing only on media coverage assuredly reduces the number of pertinent bits of information, but not nearly enough to eliminate the kaleidoscopic tendencies under analysis. Nevertheless, the emergence of the modern mass media campaign in American politics over the past two decades points to certain problematic foci worthy of special attention.

One of these is the problem of media bias. This is not, however, the ideological or partisan biases that organizational activists so often claim to exist. Rather, the media bias is always in favor of media. This bias is reflected in so many ways that analysts have great difficulty capturing it in concrete instances. It exists, nonetheless. Some examples that emerged most clearly in the 1992 campaign include the constant complaints about the "inaccessibility" of the candidates, the quadrennial emergence of complaints about the Electoral College, and the greatest outlay of funds yet for media-commissioned polls, thereby emphasizing all the more the "horserace journalism" that they decry. Moreover, the news organizations' emphasis upon policing the claims made by candidates in their speeches and advertisements can be looked at, with a cynical eye, within the context of recent studies showing that voters claim to get more voting information out of candidate-produced messages than from the news organizations themselves.

That media organizations turned more attention to policing the rhetoric of candidates, their surrogates, and their advertisements is to be commended. Yet, who polices the media? I do not mean such obvious media reports 
as tabloid exposés or the narrow partisan prattle that appears on the editorial and op-ed pages. "Responsible" media outlets do make feeble attempts to address the former and treat the latter as the province of pundits, not-quitejournalists. ${ }^{5}$ I do not intend to suggest that there are any easy solutions for such problems. Indeed, policing the media in a democratic society may be an insoluble problem if we want to keep our democracy.

Those are perennial problems, however, even if they were more pronounced in 1992. The most distinctive element in the 1992 campaign, and perhaps even more disturbing in its consequences for American politics, is a continuation of what John S. Jackson III (1986) has called the "southernization" of national elections. In essence, his argument highlights the traditional no-party politics associated with elections in the South. Indeed, the "real" elections were the primaries, where party labels had no relevance.

The most extreme form of this Southern politics is characterized by the electoral history of Arkansas (see Blair and Savage 1988). However, it is not because the winning candidate in 1992 happened to be the Governor of Arkansas that I argue that Arkansas politics has now been taken to the nation. Rather, it is because Clinton's campaign, of which he was the chief architect, proved extremely adept at manipulating the mass media election system in the direction of the personalized campaigning endemic in Arkansas politics, and thus most suited to his own electoral experience. The talk shows and the bus trips are just some of the more obvious signatures of this personalized campaign. The relative shunning of major party figures, especially congressional leaders, also heightened the personal character of the campaign. Also contributing to this personalization were factors that were not remotely available for manipulation by the Clinton organization, most notably the independent candidacy of Ross Perot and the obvious disarray of the Republican Party.

In referring to Clinton as the chief architect of his campaign, I most assuredly do not intend to say that he designed the campaign that way from the outset. He and his major advisers simply took advantage of the situations, always moving in directions that provided Clinton a familiar feeling, especially those approaches that brought him into direct contact with prospective voters - the hallmark, the essence of Arkansas politics. It was the economy that brought Clinton victory, but his campaign brilliantly avoided derailment again and again.

Finally, analyses of election campaigns all too often end as such, i.e., the electoral outcome of the balloting. Elections, however, hold whatever significance they may have only insofar as their consequences for the governing of the community. There was a time in American politics when discerning the consequences of elections was easier. Assuredly, winning 
candidates did not always pursue policies that simply mirrored the party's platform; still, there was a sense of direction and, just as importantly, a strong likelihood that the victorious candidate had the requisite skills to move public policy in that direction. The brokering skills then required for winning campaigns were much more similar to the skills required for successful governing. Today, however, the necessary campaign skills of the modern media age have little to do with those that traditionally have been required for governing.

It is this dichotomy that, more than divided partisan control, has been responsible for the gridlock in American national government. Gridlock did not begin in the 1980s; it began and persisted through the 1970s. There are signs, however, that Clinton as President will attempt not just to break gridlock, but do so by changing the fundamental style of policy leadership in American government. Already he appears to be adapting his considerable skills of personalized campaigning to the process of governing (see, e.g., Brummett 1993; Lilleston 1993; Mears 1993). If he is successful, that will be a more profound change for the American polity than any innovations that occurred during the 1992 campaign.

\section{NOTES}

*While maintaining full responsibility for what follows, the author is indebted to Diane D. Blair, Ernest Dumas, Dan Nimmo, and Bruce Plopper for their commentary on the original draft of this essay.

${ }^{1}$ This greater volume of coverage was not just a function of new venues utilized by the candidates, but of a greater volume of coverage in the traditional news media as well. See Ruszay-Sedille, 1993; Collier and Esrock, 1993.

${ }^{2}$ And for the first time in two decades, Senator Edward Kennedy came nowhere close to surfacing as a contender for the Democratic nomination. On the other hand, former nominee George McGovern splashed noisily but briefly, receiving no serious attention from the media brokers, the media consultants, or the financial backers, all necessary for modern presidential campaigns. See Savage (1986) and Trent (1978) on the related processes of surfacing and winnowing in the early presidential campaign.

${ }^{3}$ Thus, support of "family values" also became part of the policy agenda in the campaign, another issue that received considerable media attention and, given the pluralism endemic in American society, did little good for the Bush campaign (see, e.g., Barone 1992).

${ }^{4}$ This was not Clinton's first appearance on a late-night talk show. On July 28, 1988, he playfully traded quips with Johnny Carson on The Tonight Show. For that matter, the first appearance of a presidential candidate on a television entertainment program dates much earlier. On September 16, 1968, Republican contender Richard Nixon appeared on Rowan and Martin's Laugh-In, where he spoke that program's most notable recurring phrase, "Sock it to me," but as an interrogative, not a declarative statement.

${ }^{5}$ The irony in the latter case, however, is that much of what is reported in media news is the words, the insights, passions, maxims, and prophecies, of pundits. On this and other matters relating to the rise of "punditocracy," see Nimmo and Combs (1992). 


\section{REFERENCES}

Anderson, Jack. 1992a. Democrats Set for '92 "Horton” Attack. Arkansas Democrat-Gazette 11 July: $3 \mathrm{E}$.

1992b. Dirty Fight Ahead in Fall Campaign. Arkansas Democrat-Gazette 10 June: 3F.

Barone, Michael. 1992. America's “Culture Wars” Tradition. U.S. News \& World Report 118 (21 September): 24.

Blair, Diane D. and Robert L. Savage. 1988. The Appearances of Realignment and Dealignment in Arkansas. In Robert H. Swansbrough and David M. Brodsky, eds., The South's New Politics: Realignment and Dealignment. Columbia: University of South Carolina Press.

Blumenthal, Sidney. 1992. Reporters Grumbling about Lack of Access to Clinton. Arkansas DemocratGazette 6 June: 14A.

Brummett, John. 1992. The Hipster Wearing the Shades on TV was Real. Arkansas Democrat-Gazette 7 June: $5 \mathrm{~J}$.

1993. Using Show Business. Arkansas Democrat-Gazette 12 January: 9B.

Collier, Ken and Stuart L. Esrock. 1993. Who Gets What from the Networks? Network Coverage of the 1992 Presidential Primaries. Paper presented at the Annual Meeting of the Southwestern Political Science Association, New Orleans.

Dowd, Maureen, 1992. Of Knights and Presidents: Race of Mythic Proportions. New York Times 10 October: A1, A9.

Election Debriefing. 1992. Philadelphia: Annenberg School for Communication, University of Pennsylvania, 12 December. Videocassette.

Entertainment Weekly. 10 July 1992. Everybody's Talkin'. No. 126: 16-18.

Gergen, David. 1992. Was the Press Unfair to Bush. U.S. News \& World Report 118 (9 November): 100.

Golson, Barry, and Peter Ross Range. 1992a. Clinton on TV. TV Guide 40 (21 November): 14-18. . 1992b. Wotta year! TV Guide 40 (November 7): 16-20.

Jackson, John S. III. 1986. The Southernization of National Politics. Plenary address at the Annual Meeting of the Arkansas Political Science Association, North Little Rock.

Lilleston, Randy. 1993. Clinton Revives Campaign Atmosphere. Arkansas Democrat-Gazette 3 February: $8 \mathrm{~A}$.

Mears, Walter. 1993. Clinton Revisits Favorite Campaign Tactic. The Morning News (Springdale, AR), 13 February.

Nimmo, Dan and James E. Combs. 1992. The Political Pundits. New York: Praeger.

Nimmo, Dan and Robert L. Savage. 1976. Candidates and Their Images: Concepts, Methods, and Findings. Pacific Palisades, CA: Goodyear.

Norberg, Bob. 1992. Stations Pull Ad Questioning Clinton Stand on Gay Rights. Arkansas DemocratGazette 10 October: 12A.

Oman, Noel. 1992. Reporters Grumbling about Lack of Access to Clinton. Arkansas Democrat-Gazette 6 June: $14 \mathrm{~A}$

Public Perspective, The. 1993. Problems in Exit Polling: Interviews with Warren J. Mitofsky and John Brennan. The Public Perspective 4 (January/February): 19-23.

Rindy, Dean. 1992. Ads Don't Change_Candidates Do. Campaigns \& Elections 13 (July): 55.

Ruszay-Sedille, Kathleen C. 1993. 1988-1992: Has Anything Changed? A Comparative Analysis of Newspaper Coverage of the Presidential Elections. Paper presented at the Annual Meeting of the Southwestern Political Science Association, New Orleans.

Savage, Robert L. 1986. Statesmanship, Surfacing, and Sometimes Stumbling: Constructing Candidate Images During the Early Campaign. Political Communication Review 11: 43-57.

Solomon, John. 1992. Maverick Ads Spice Up Voting Season. Arkansas Democrat-Gazette 1 November: $21 \mathrm{~A}$.

Trent, Judith S. 1978. Presidential Surfacing: The Ritualistic and Crucial First Act. Communication Monographs 45: 281-292. 